\title{
Aborsi dalam Perspektif Hak Asasi Manusia dan Hukum Islam (Analisis terhadap Peraturan Pemerintah No. 61 tahun 2014 tentang Kesehatan Reproduksi)
}

\author{
Linda Firdawaty
}

\begin{abstract}
Abortion in the Perpectives of Human Rights and Islamic Law (An Analysis of Government Regulation No. 61/2014 on Reproductive Health). This article examines the Government Regulation PP No. 61 of 2014 regulating mechanism and procedures of abortion in the case of rape victims from the perspectives of Human Rights and Islamic Law. The regulation, which is the implementation of Article 75 paragraph (1) of the Health Act, states that abortion is prohibited unless there is an indication of medical emergency and pregnancy due to rape. According to the rules, the implementation of abortion must fulfill some procedures such as:pregnancy verification, doctor's certificate, investigator's statement, and psychologist's information about the occurrence of rape. In 39/1999 ofHuman Rights Act, unless it is aimed atprotecting the mother and child's life, abortionis considered as violating human rights. In Islamic law, the regulation of abortion for rape victims varies widely, depending on circumstances.
\end{abstract}

Keywords: abortion in Islam, human rights, positive law, reproductive health

\begin{abstract}
Abstrak: Aborsi dalam Perspektif Hak Asasi Manusia dan Hukum Islam (Analisis terhadap Peraturan Pemerintah No. 61 tabun 2014 tentang Kesehatan Reproduksi). Artikel ini menelaah bagaimana PP No. 61 Tahun 2014 mengatur tentang mekanisme dan prosedur aborsi bagi korban perkosaan dari perpektif HAM dan Hukum Islam. Peraturan Pemerintah ini merupakan pelaksanaan dari Pasal 75 ayat (1)UU Kesehatan, yang menyebutkan bahwa aborsi dilarang terkecuali ada indikasi kedaruratan medis dan kehamilan akibat perkosaan. Menurut peraturan tersebut pelaksanaan aborsiharus memenuhi prosedur pembuktian berupa pembuktian usia kehamilan melalui surat keterangan dokter, keterangan penyidik dan keterangan psikolog tentang terjadinya perkosaan. Menurut hukum Islam, hukum melakukan aborsi bagi korban perkosaan berbeda-beda tergantung situasi dan kondisi. Sementara Menurut Undang -Undang No 39 Tahun 1999 tentang HAM aborsi hanya boleh dilakukan untuk melindungi jiwa ibu dan anak, alasan selain itu dianggap melanggar HAM.
\end{abstract}

Kata Kunci: aborsi dalam Islam, HAM, hukum positif, kesehatan reproduksi 


\section{Pendahuluan}

Pergaulan bebas antara laki-laki dan perempuan di luar pernikahan, terutama para pelajar dan mahasiswa saat ini sudah sampai batas yang sangat mengkhawatirkan. Ini akibat melemahnya nilai-nilai agama dalam kehidupan masyarakat, ditambah lagi dengan perkembangan teknologi informasi, yang memudahkan akses untuk mencari berbagai macam informasi, terkadang disalahgunakan oleh anak-anak ataupun remaja. Di samping itu, gencarnya media massa yang menawarkan kehidupan glamor, bebas dan serba hedonis yang menyebabkan generasi muda terseret dalam jurang kehancuran.

Data statistis BKBN (Badan Koordinasi Keluarga Berencana Nasional) menunjukkan bahwa sekitar 2.000.000 kasus aborsi terjadi setiap tahun di Indonesia. Untuk kasus aborsi di luar negeri khususnya di Amerika data-datanya telah dikumpulkan oleh dua badan utama, yaitu Federal Centers for Disease Control (CDC) dan Alan Guttmacher Institute (AGI) yang menunjukkan hampir 2 juta jiwa terbunuh akibat aborsi. Jumlah ini jauh lebih banyak dari jumlah nyawa manusia yang dibunuh dalam perang manapun dalam sejarah negara itu. Begitu juga lebih banyak dari kematian akibat kecelakaan, maupun akibat penyakit. ${ }^{1}$ (DIHAPUS)

Walaupun secara tegas aborsi dilarang oleh undang-undang, ${ }^{2}$ kecuali

${ }^{1}$ Ahmad Zain, "Hukum Aborsi dalam Islam," 19 Oktober 2014, http//www.ahmadzain. $\mathrm{com} / \mathrm{read} /$ karya-tulis/258/Legalitas-Aborsi-Terhadap-Korban-Perkosaan-Menurut-PP-No-17Tahun-2014.html. (DIHAPUS)

2 Terkait hal ini telah banya artikel yang membahas tentang aborsi karena melanggar undang-undang dan hak asasi manusia, namun terkait analisis Peraturan Pemerintah Peraturan Pemerintah No. 61 tahun 2014 tentang Kesehatan Reproduksi belum ada yang membahas. Terkait selain hal itu, sudah pernah ada yang membahas di antaranya Riza Yuniar Sari, "Aborsi Korban Perkosaan Perspektif Hukum Islam dan Hak Asasi Manusia”, AL-HUKAMA The Indonesian Journal of Islamic Family Law 03, No. 01, (Juni 2013): h. 34-81. Paulinus Soge. "Hukum Aborsi Tinjauan Politik Hukum Pidana Terhadap Perkembangan Hukum Aborsi di Indonesia." Jurnal Hukum (2010): h. 1-98. T. R., Andayani, and I. Setiawan. "Perilaku Seksual Pranikah dan Sikap Terhadap Aborsi." Jurnal Psikologi 2 (2005): h. 1-9. Annette Anasthasia Napitupulu, and Mahmud Mulyadi. "Pembaharuan Hukum Pidana Terhadap Tindak Pidana Aborsi di Indonesia." Jurnal Mahupiki 1, no. 1 (2013). Paulus Benny Halim. "Abortus Provocatus dalam Perspektif Hak Asasi Manusia." PhD diss., UAJY, 2010. Mutiara Puspa Rani. "Analisis Dekriminalisasi Aborsi dalam Peraturan Pemerintah No. 61 Tahun 2014 Tentang Kesehatan Reproduksi." Jurnal Poenale 3, no. 4 (2015). Yuli Susanti. "Perlindungan Hukum Bagi Pelaku Tindak Pidana Aborsi (Abortus Provocatus) Korban Perkosaan.” Syiar Hukum 14, no. 2 (2012): h. 79-93. Novianus Tangko. "Tindak Pidana dengan Sengaja Mengobati untuk Menggugurkan Kandungan (Abortus Provocatus) 
karena alasan tertentu, dalam realita kehidupan sehari-hari, hal tersebut banyak sekali terjadi atau dilakukan karena berbagai alasan sebagaimana dikemukakan oleh Ekotama, dkk. ${ }^{3}$ Dewi ${ }^{4}$ menyatakan, bahwa jumlah aborsi dalam kehidupan masyarakat cenderung meningkat karena berbagai faktor sehingga dia menyimpulkan bahwa motivasi perempuan melakukan aborsi berkaitan erat dengan akseptor KB dan kehamilan di luar nikah. ${ }^{5}$

Berbeda dengan pendapat di atas, menurut Indraswari, kasus aborsi tidak menunjukkan karakteristik khusus terutama bila dilihat dari segi pendidikan dan status pernikahan. Ada kecenderungan, aborsi adalah suatu fenomena yang menimpa masyarakat lintas strata sosial ekonomi, pendidikan, budaya, dan agama ${ }^{6}$. Selanjutnya Indraswati mengatakan:

... terdapat kecenderungan peningkatan praktik aborsi yang dilakukan oleh pelajar SMP dan SMA, alumnus SMA (pekerja), dan mahasiswa. Hal ini sejalan dengan perubahan pola interaksi dan pola gaya hidup yang melanda kalangan remaja dan dewasa muda. ${ }^{7}$

dalam Pasal 299 KUHPidana." Lex Crimen 5, no. 2 (2016). Riza Yuniar Sari. "Aborsi Korban Perkosaan Perspektif Hukum Islam dan Hak Asasi Manusia." Al-Hukama’ 3, no. 1 (2013): h. 34-82. Yuke Novia Langie. "Tinjauan Yuridis Atas Aborsi di Indonesia (Studi Kasus di Kota Manado)." Lex et Societatis 2, no. 2 (2014). Titik Kuntari, Siswanto Agus Wilopo, and Ova Emilia. "Determinan Abortus di Indonesia." Kesmas: National Public Health Journal 4, no. 5 (2010): h. 223-229. Paulinus Soge. "Legalisasi Aborsi di Indonesia Perspektif Perbandingan Hukum Pidana: Antara Common Law System dan Civil Law System.” Jurnal Hukum 16, no. 4 (2009): h. 441-596. Claudia Surjadjaja. "Policy Analysis of Abortion in Indonesia: The Dynamic of State Power, Human Need and Women's Right." IDS bulletin 39, no. 3 (2008): h. 62-71.

${ }^{3}$ Ekotama, dkk, Abortus Provocatus Bagi Korban Perkosaan: Perspektif Viktimologi, Kriminologi dan Hukum Pidana (Yogyakarta: Universitas Atmajaya, 2001), h. 26.

${ }^{4}$ Dewi, Aborsi: Pro dan Kontra di Kalangan Petugas Kesehatan (Yogyakarta: Pusat Penelitian Kependudukan UGM dan Ford Foundation, 1997), h. 40.

${ }^{5}$ Terkait faktor-faktor aborsi bisa dilihat dalam beberapa artikel di antaranya Dien GA Nursal. "Faktor-faktor yang Berhubungan dengan Perilaku Seksual Murid SMU Negeri di Kota Padang tahun 2007." Jurnal Kesehatan Masyarakat Andalas 2, no. 2 (2008): 175-180. Setia Pranata, and F. X. Sadewo. "Kejadian Keguguran, Kehamilan Tidak Direncanakan dan Pengguguran di Indonesia." Buletin Penelitian Sistem Kesehatan 15, no. 2 April (2012). Terence H. Hull, Sarsanto W. Sarwono, and Ninuk Widyantoro. "Induced Abortion in Indonesia." Studies in Family Planning (1993): 241-251. Yayah Khisbiyah. "Konsekuensi Psikologis dan Sosial-Ekonomi Kehamilan Tak Dikehendaki Pada Remaja.” Populasi 5, no. 2 (1994). Masri Singarimbun. "Beberapa Aspek Aborsi." Populasi 5, no. 2 (1994).

${ }^{6}$ Indraswati, "Fenomena Kawin Muda dan Aborsi: Gambaran Kasus," dalam Hasyim S, Menakar 'Harga' Perempuan (Jakarta: Mizan, 1999), h. 150.

${ }^{7}$ Hasyim S, Menakar 'Harga' Perempuan, h. 150. 
Apa yang dikemukan tersebut cukup beralasan, di wilayah perkotaan dan semi perkotaan hubungan antar individu secara perlahan namun pasti bertransformasi dari hubungan berpola paguyuban (gemeinschaft) ke hubungan berpola patembayan (gesselschaft). Pola hubungan paguyuban yang berciri kebersamaan dan saling peduli pada masalah sesama anggota komunitas mulai digeser oleh pola patembayan yang berciri hubungan transaksional. Dalam derajat tertentu, pola patembayan diikuti dengan lemahnya kontrol sosial masyarakat terhadap sesama.

Dengan pola interaksi seperti ini yang diikuti perubahan pola gaya hidup yang cenderung "serba permisif" mengakibatkan meningkatnya kasus kehamilan pranikah. Ditambah lagi adanya stimulasi seksual dari lingkungan berupa tayangan media massa dan hiburan komersial dengan beragam bentuk dan intensitas yang secara umum merupakan komersialisasi hiburan yang lebih mengkampanyekan aspek kenikmatan seks dari pada aspek tanggung jawabnya.

Dalam kondisi ini dalam derajat tertentu dapat dipahami "runtuhnya" daya tahan remaja dalam menghadapi kebanjiran stimulasi seksual yang mengakibatkankehamilan pranikah dan selanjutnya diikuti oleh tindakan aborsi. Meski demikian, secara kritis bisa ditarik generalisasai bahwa aborsi dilakukan tidak hanya dikarenakan kehamilan di luar perkawinan, tetapi juga terjadi di dalam perkawinan, oleh perempuan yang berstatus istri. Baik abortus dikarenakan kehamilan di luar perkawinan ataupun dalam perkawinan, keduanya memiliki beberapa alasan yang berbeda, dan keduanya merupakan fenomena terselubung yang cenderung ditutupi oleh pelakunya.

Lahirnya Peraturan Pemerintah (PP) Nomor 61 Tahun 2014 tentang Kesehatan Reproduksi, yang membolehkan praktik aborsi atau legalisasi aborsi telah menimbulkan keresahan dan kontroversi di tengah masyarakat. Peraturan Pemerintah (PP) Nomor 61 Tahun 2014 tentang Kesehatan Reproduksi ini merupakan pelaksanaan dari Pasal 75 ayat (1) UU Kesehatan, bahwa aborsi dilarang terkecuali ada indikasi kedaruratan medis dan kehamilan akibat perkosaan yang dapat menimbulkan trauma psikologis bagi korban perkosaan.

Banyak tokoh agama menghimbau kepada pemerintah untuk me- 
ninjau kembali PP tersebut. Langkah ini guna menghindarkan sebagian masyarakat atau tenaga medis yang cenderung pragmatis. Jika tidak, maka praktik aborsi bisamenggejala terutama di kalangan remaja yang selama ini telah dikhawatirkan semakin banyak yang melakukan hubungan seks bebas. PP tentang legalisasi aborsi ini bisa dimanfaatkan juga untuk sengaja menggugurkan janin dalam kandungan karena tidak dikehendaki.

Berdasarkan PP yang baru itu, tindakan aborsi hanya dapat dilakukan berdasarkan indikasi kedaruratan medis dan kehamilan akibat perkosaan. Seperti Pasal 75 UU Kesehatan, PP ini juga menyatakan bahwa aborsi akibat perkosaan hanya dapat dilakukan apabila usia kehamilan paling lama berusia 40 (empat puluh) hari dihitung sejak hari pertama haid terakhir. Sementara yang dimaksud indikasi kedaruratan medis adalah: a. Kehamilan yang mengancam nyawa dan kesehatan ibu; dan/atau b. Kesehatan yang mengancam nyawa dan kesehatan janin, termasuk yang menderita penyakit genetik berat dan atau cacat bawaan, maupun yang tidak dapat diperbaiki sehingga menyulitkan bayi tersebut hidup di luar kandungan.

Penilaian atas indikasi medis dilakukan oleh paling sedikit terdiri dari 2 (dua) orang tenaga kesehatan, yang diketuai dokter yang memiliki kompetensi dan kewenangan. Di samping itu, indikasi adanya perkosaan adalah jika ada unsur pemaksaan, adanya gangguan psikologis akibat perkosaan tersebut, yang perlu melalui tahapan pemeriksaan oleh tim ahli, sehingga perkosaan dapat dibuktikan, bukan hanya alasan yang dibuat-buat. Adanya indikasi medis dan korban perkosaan inilah yang menimbulkan kontroversi, karena dikaitkan dengan asumsi adanya pembenaran legalisasi aborsi.

Legalisasi aborsi korban perkosaan ini bertujuan untuk melindungi masa depan korban perkosaan. Untuk menghindarkan trauma psikologis dan beban sosial wanita korban perkosaan. Alasan ini juga dijadikan argumen bagi pendukung legalisasi aborsi sebagai realisasi penegakan Hak Asasi Manusia. Wanita korban perkosaan juga memiliki kebebasan menentukan sesuatu atas dirinya, apalagi menyangkut kehamilan yang tidak diinginkan itu akan memberi dampak sosial dan psikologis. Jika wanita korban perkosaan ingin melakukan aborsi, itu juga semata-mata 
karena mereka juga mempunyai hak asasi untuk menentukan kehidupan pribadinya yang bebas dari tekanan psikologis dan sosial akibat kehamilan yang tidak dikehendaki tersebut.

Dengan alasan melindungi hak asasi wanita korban perkosaan, serta melindungi masa depannya. Sementara janin yang ada dalam kandungan wanita tersebut juga mempunyai hak untuk hidup, perlu dilindungi. Terjadi benturan antara kepentingan melindungi hak asasi janin yang akan tumbuh dalam rahim dengan hak ibu yang ingin terlepas dari beban psikologis dan sosial. Di sisi lain, Islam bukanlah agama yang kaku, tetapi dinamis, yang memandang kehidupan manusia ini dari berbagai sudut, sehingga dari berbagai permasalahan yang dihadapi manusia dapatditemukan solusinya.

Oleh karena itu, perlu dikaji prosedur pemeriksaan terhadap korban perkosaan sebelum melakukan tindakan aborsi dan bagaimana hukum melakukan aborsi menurut Hak Asasi Manusia dan Hukum Islam. Terjadi kontroversi tentang legalisiasi aborsi menurut PP No 61 Tahun 2014 tentang kesehatan reproduksi. Berdasarkan uraian tersebut, maka permasalahan dalam tulisan ini adalah bagaimana prosedur periksaan terhadap korban perkosaan sebelum melakukan aborsi? bagaimana hukum melakukan aborsi bagi korban perkosaan menurut PP No. 61 Tahun 2014 tentang kesehatan reproduksi dalam perspektif hak asasi manusia (HAM) dan hukum Islam?

\section{Metode Penelitian}

Penelitian ini menggunakan pendekatan yuridis-normatif, yaitu pendekatan yang didasarkan pada peraturan perundang-undangan, teoriteori, dan konsep-konsep yang berhubungan dengan cakupan hukum melakukan aborsi baik secara umum, ataupun karena adanya alasan medis dan korban perkosaan. Sumber data dalam penelitian ini adalah data kepustakaan, sedangkan jenis data yang dibutuhkan dalam penelitian ini adalah data sekunder.

Data sekunder merupakan data yang diperoleh dari studi kepustakaan terhadap bahan-bahan hukum atau referensi yang berkaitan dengan permasalahan penelitian. Studi kepustakaan dilakukan terhadap bahan- 
bahan hukum yang berkaitan dengan permasalahan penelitian yaitu tentang aborsi menurut ketentuan perundang-undangan, serta hukum Islam. Data yang dibutuhkan meliputi:

1. Bahan hukum primer, yaitu bahan hukum yang mempunyai kekuatan mengikat secara umum, seperti Alquran dan hadis, peraturan perundang-undangan dan putusan pengadilan (hakim),

2. Bahan hukum sekunder, yaitu bahan hukum yang memberi penjelasan terhadap bahan hukum primer, seperti literatur-literatur, media cetak atau elektronik khususnya yang berkaitan dengan permasalahan penelitian yaitu hukum melakukan aborsi bagi korban perkosaan menurut PP No 61 Tahun 2014.

3. Bahan hukum tersier, yaitu bahan hukum yang memberi penjelasan terhadap bahan hukum primer dan bahan hukum sekunder, seperti kamus atau ensiklopedia.

Pengumpulan data (sekunder) dilakukan dengan menggunakan studi pustaka, dengan cara membaca, menyalin, mengutip, dan menelaah bahan-bahan hukum yang berkaitan dengan permasalahan penelitian. Baik terhadap bahan hukum primer, bahan hukum sekunder, maupun bahan hukum tersier.

Data yang terkumpul selanjut diolah, pengolahan data dilakukan dengan cara: 1) Pemeriksaan data, dilakukan untuk mengetahui apakah data yang diperoleh sudah sesuai dengan permasalahan, dapat dipertanggungjawabkan secara ilmiah. 2) Klasifikasi data dilakukan sesuai dengan kriteria atau pokok-pokok bahasan masing dalam rangka menjawab permasalahan dalam penelitian. 3) Rekonstruksi data, yaitu menyusun ulang data secara teratur, berurutan, dan logis sehingga mudah dipahami dan diinterpretasikan. 4) Sistematisasi data, yaitu menempatkan data menurut kerangka sistematika pembahasan berdasarkan urutan permasalahan dalam penelitian.

Analisis data dilakukan dalam bentuk analisis kualitatif, yaitu dengan cara menguraikan data dalam bentuk kalimat yang tersusun secara sistematis, lengkap, dan terperinci menurut pokok bahasan yang telah ditentukan, hal ini guna memudahkan interpretasi dan menarik kesimpulan sebagai jawaban permasalahan penelitian. Hasil analisis dan 
pembahasan tersebut kemudian ditulis dalam bentuk laporan penelitian yang mendeskripsikan secara lengkap, jelas, dan sistematis.

\section{Legalisasi Aborsi menurut UU No 36 tentang Kesehatan dan PP No. 61 Tahun 2014 tentang Kesehatan Reproduksi}

Menurut ilmu kedokteran, aborsi dibagi menjadi dua yaitu:

1. Aborsi spontan (Abortus Spontaneus), yaitu aborsi yang terjadi tanpa ada unsur tindakan dari luar, terjadi dengan sendirinya dan biasanya disebut keguguran.

2. Aborsi buatan (Aborsi Provocatus), yaitu aborsi yang dilakukan secara sengaja dengan tujuan tertentu. Aborsi Provocatus ini dilakukan berdasarkan:

a. Indikasi medis yaitu menghilangkan kehamilan untuk menyelamatkan jiwa ibu karena adanya indikasi penyakit jantung, ginjal dan penyakit hati berat yang lain serta gangguan pertumbuhan dan perkembangan janin dalam rahim. ${ }^{8}$ Aborsi karena alasan medis ini disebut dengan Abortus Profocatus Therapeuticum. Abortus provacatus therapeutik dilakukan oleh dua orang dokter (salah satunya harus spesialis), sependapat bahwa kesehatan mental dan fisik ibu atau anaknya terancam atau bahaya cacat janin sangat serius 9

b. Indikasi sosial, pengguguran kandungan dilakukan atas alasan sosial seperti tidak ingin punya anak, jarak kehamilan terlalu pendek, belum siap untuk hamil dan kehamilan yang tidak diinginkan ${ }^{10}$ Jika dilakukan karena alasan yang bukan medis dan melanggar hukum yang berlaku, maka disebut Abortus Profocatus Criminalis.

${ }^{8}$ Icesmi Sukarni K dan Margareth ZH, Kehamilan, Persalinan dan Nifas (Numed, 2013), h. $165-166$.

${ }^{9}$ C. Dalto A. Schiffmen dan P. Bello, Mencegah dan Merencanakan Kehamilan (Arcan, 1991), h. 162.

${ }^{10}$ Icesmi Sukarni K dan Margareth ZH, Kehamilan, Persalinan dan Nifas, h. 166. 
Pasal Pasal 75 ayat (1) Undang-undang No. 36 Tahun 2009 tentang Kesehatan menyatakan bahwa aborsi dilarang terkecuali ada indikasi kedaruratan medis dan kehamilan akibat perkosaan yang dapat menimbulkan trauma psikologis bagi korban perkosaan. Sejalan dengan itu pada tanggal 21 Juli 2014, Pemerintah mengeluarkan Peraturan Pemerintah (PP) Nomor 61 Tahun 2014 tentang Kesehatan Reproduksi. PP ini merupakan peraturan pelaksanaan dari UU No. 36 Tahun 2009 tentang Kesehatan khususnya pasal 75, 126, dan 127.Bagian yang menjadi sorotan adalah legalisasi aborsi untuk korban perkosaan.

Pasal 31 (1) PP No 61 Tahun 2014 mengatur bahwa kehamilan akibat perkosaan merupakan kehamilan hasil hubungan seksual tanpa adanya persetujuan dari pihak perempuan sesuai dengan ketentuan peraturan perundang-undangan. Ayat (2) Kehamilan akibat perkosaan sebagaimana dimaksud pada ayat (1) dibuktikan dengan usia kehamilan sesuai dengan kejadian perkosaan, yang dinyatakan oleh surat keterangan dokter; dan adanya keterangan penyidik, psikolog, dan/atau ahli lain mengenai adanya dugaan perkosaan.

PP ini juga menyatakan bahwa aborsi akibat perkosaan hanya dapat dilakukan apabila usia kehamilan paling lama berusia 40 (empat puluh) hari dihitung sejak hari pertama haid terakhir. Sementara yang dimaksud indikasi kedaruratan medis adalah:

1. Kehamilan yang mengancam nyawa dan kesehatan ibu; dan/atau

2. Kesehatan yang mengancam nyawa dan kesehatan janin, termasuk yang menderita penyakit genetik berat dan atau cacat bawaan, maupun yang tidak dapat diperbaiki sehingga menyulitkan bayi tersebut hidup di luar kandungan. Penilaian atas indikasi medis dilakukan oleh paling sedikit terdiri dari 2 (dua) orang tenaga kesehatan, yang diketuai dokter yang memiliki kompetensi dan kewenangan.

\section{Prosedur Aborsi Korban Perkosaan Menurut PP No. 61 Tahun 2014 Tentang Kesehatan Reproduksi}

Prosedur pemeriksaan terhadap korban perkosaan sebelum dilakukan tindakan aborsi adalah melalui pemeriksaan oleh tim kelayakan aborsi. 
Tim ini yang akan memutuskan apakah kehamilan tersebut layak atau tidak untuk aborsi. Tim ini terdiri dari minimal 2 (dua) orang tenaga kesehatan yang diketuai oleh dokter yang memiliki kompetensi dan kewenangan.

Prosedur pemeriksaan ini dapat kita pakai istilah 'paket lengkap', bahwa PP ini sudah mengatur dengan cukup rinci tentang bagaimana prosedur tindakan aborsi dilakukan. Untuk kondisi darurat medis: assesment dari tim kelayakan-konseling pra tindakan-(jika dilakukan tindakan aborsi maka berlanjut dengan konseling pasca-tindakan). Untuk kondisi korban perkosaan: pembuktian sebagai korban perkosaan (Usia kehamilan sesuai keterangan dari penyidik, keterangan dari psikolog, yang menguatkan adanya dugaan perkosaan)-pembatasan usia kehamilan (maksimal 40 hari)-kemudian konseling pra tindakan-(jika dilakukan tindakan aborsi maka berlanjut dengan konseling pasca-tindakan).

Prosedur pemeriksaan yang dikenal dengan istilah "paket lengkap" berupa:

1. Pembuktian. Kehamilan akibat perkosaan dalam pasal ini harus dibuktikan dengan:

a. Usia kehamilan yang sesuai dengan kejadian perkosaan yang dinyatakan oleh surat keterangan dokter.

b. Keterangan dari penyidik.

c. Keterangan dari psikolog, dan atau ahli lainnya mengenai adanya dugaan perkosaan.

2. Konseling pra-tindakan, bertujuan untuk:

a. Mengetahui apa yang dibutuhkan oleh perempuan yang mengajukan aborsi

b. Menginformasikan pada perempuan tersebut apakah tindakan aborsi dapat atau tidak dapat dilakukan berdasarkan hasil pemeriksaan klinis dan pemeriksaan penunjang

c. Menjelaskan tentang apa dan bagaimana efek samping dari tindakan aborsi atau kemungkinan komplikasi.

d. Membantu perempuan tersebut untuk mengambil keputusannya sendiri, apakah akan melakukan aborsi atau membatalkan aborsi. 
e. Konselor menilai bagaimana kesiapan perempuan dalam menjalankan aborsi. Katakanlah, kemudian tindakan aborsi dilakukan. Maka prosedur dalam 'paket lengkap' selanjutnya adalah konseling pasca tindakan.

3. Konseling pasca tindakan bertujuan untuk:

a. Mengevaluasi kondisi pasien setelah tindakan aborsi,

b. Membantu pasien memahami keadaan atau kondisi fisik setelah menjalankan aborsi,

c. Menjelaskan perlunya kunjungan ulang pemeriksaan dan konseling lanjutan atau tindakan rujukan bila diperlukan.

Kebolehan aborsi bagi korban perkosaan hanya terbatas jika aborsi dinyatakan layak untuk dilakukan oleh tim kelayakan aborsi. Aborsi tidak dapat dilakukan jika hanya alasan yang di rekayasa, seperti kehamilan akibat pergaulan bebas, kemudian mengaku sebagai korban perkosaan.

Hanya saja ada kekhawatiran tentang aplikasi "paket lengkap" ini dalam kehidupan masyarakat Indonesia. Mengenai integritas dari pemohon tindakan aborsi, atau termohon tindakan aborsi. Ditambah lagi kekhawatiran adanya oknum yang memanfaatkan kebijakan ini untuk melegalkan aborsi. Dalam konteks lain, misalnya dalam melakukan studi kelayakan aborsi, dikhawatirkan terjadi praktik suap dan pemerasan yang dilakukan oleh masyarakat sebagai penyuap misalnya, atau aparatur pemerintah (oknum) yang aktif melakukan pemerasan.

\section{Aborsi bagi Korban Perkosaan dalam Perspektif HAM dan Hukum Islam}

\section{Aborsi bagi Korban Perkosaan dalam Perspektif HAM}

Secara yuridis jelas bahwa HAM terkait dengan sesuatu yang mendasar dalam kehidupan manusia. Hak asasi manusia merupakan hak dasar yang secara kodrati melekat pada diri manusia, bersifat universal dan langgeng. Oleh karena itu harus dilindungi, dihormati, dipertahankan, dan tidak boleh diabaikan, dikurangi, atau dirampas oleh siapapun. Hak 
asasi menggambarkan sesuatu yang melekat dalam diri manusia, baik akibat hukum Negara maupun ketentuan dari Tuhan. ${ }^{11}$

Menurut Baharuddin Lopa (1996), bahwa di dalam Piagam Universal Hak Asasi Manusia yang dikenal dengan UDHR (Universal Declaration of Human Rights) juga diatur tentang hak kesehatan dan hidup manusia. Mengenai hak hidup dan keselamatan disebutkan dalam Pasal 3, bahwa setiap orang berhak atas kehidupan, bebas merdeka dan keamanan (keselamatan) sebagai individu. ${ }^{12}$

UU No 39 Tahun 1999 tentang HAM mengatur tentang hak-hak yaitu hak untuk hidup, hak berkeluarga dan melanjutkan keturunan, hak mengembangkan diri, hak memperoleh keadilan, hak atas kebebasan pribadi, hak atas rasa aman, hak atas kesejahteraan, hak turut serta dalam pemerintahan, hak wanita, dan hak anak.

Mengenai hak untuk hidup, Pasal 9 (1) Undang-undang Nomor 39 Tahun 1999 tentang Hak Asasi Manusia, mengatur bahwa setiap orang berhak untuk hidup, dan mempertahankan hidup dan meningkatkan taraf kehidupannya. Ketentuan ini menunjukkan bahwa hak untuk hidup merupakan hak mendasar yang melekat atau dimiliki seseorang sebagai karunia Tuhan. Selanjutnya pada pasal 53 (1) Undang-Undang Hak Asasi Manusia mengatur tentang hak anak. Dalam pasal tersebut dinyatakan bahwa setiap anak dalam kandungan berhak untuk hidup, mempertahankan hidup dan meningkatkan taraf kehidupannya.

Sejalan dengan Undang-Undang HAM, maka Undang-Undang No. 22 Tahun 2002 tentang Perlindungan Anak juga mengatur tentang perlindungan anak. Perlindungan anak adalah segala kegiatan untuk menjamin dan melindungi anak dan hak-haknya agar dapat hidup, tumbuh, berkembang dan berpartisipasi secara optimal sesuai dengan harkat, martabat kemanusiaan. ${ }^{13}$

${ }^{11}$ Nur Chozin Askandar, “Hak Untuk Hidup' dalam Kajian Islam dan Hak Asasi Manusia,” Jurnal An-Natiq, Universitas Islam Malang, (2012), h. 54.

${ }^{12}$ Munir Syahrizal, Hak Asasi Manusia: Keadidayaan Kejahatan Kemanusiaan (Jakarta: Presssindo Akademika, 2013), h. 21.

${ }^{13}$ Muladi, Hak Asasi Manusia, Hakekat, Konsep dan Implikasinya dalam Perspektif Hukum dan Masyarakat (PT. Rafika Aditama, 2009), h. 233. 
Kewajiban memberikanperlindungan bagi anak merupakan kewajiban orang tua, keluarga, masyarakat, pemerintah dan Negara secara terus menerus demi terlindunginya hak-hak anak. Orang tua berkewajiban dan bertanggung jawab untuk mengasuh, memelihara, mendidik dan melindungi anak. Undang-undang perlindungan anak bahkan telah memberikan sanksi pidana bagi mereka yang tidak menjalankan ketentuan undang-undang tentang perlindungan anak.

Berdasarkan kedua pasal dalam Undang-Undang HAM tentang hak hidup bagi setiap orang bahkan anak dalam kandungan mengandung makna larangan melakukan pembunuhan. Apalagi orang tua sebagai orang yang sangat bertanggung jawab untuk memelihara dan melindungi anak dari segala sesuatu yang dapat merusak masa depannya. Perbuatan aborsi yang dilakukan oleh ibu kandung yang seharusnya menjaga dan melindungi anak sesungguhnya merupakan perbuatan yang sangat keji. Aborsi adalah tindakan pembunuhan, yang berarti aborsi adalah perbuatan yang dilarang.

Pasal yang melegalkan aborsi karena korban perkosaan ini secara filosofis bertujuan untuk melindungi wanita korban perkosaan dari gangguan psikologis maupun trauma sosial karena harus menanggung resiko kehamilan sendiri tanpa ada yang bertanggung jawab. Dengan alasan melindungi hak asasi wanita korban perkosaan, serta melindungi masa depannya. Sementara janin yang ada dalam kandungan wanita tersebut juga mempunyai hak untuk hidup, perlu dilindungi. Terjadi benturan antara kepentingan melindungi hak asasi janin yang akan tumbuh dalam rahim dengan hak ibu yang ingin terlepas dari beban psikologis dan sosial.

Menurut UU No 39 Tahun 1999 tentang HAM, hak hidup atau melanjutkan kehidupan itu dibutuhkan manusia (janin maupun ibu) selain untuk melindungi diri dan martabat kemanusiaanya juga digunakan sebagai landasan moral dan keagamaan dalam bergaul atau berhubungan dengan sesama manusia dan Tuhan. Ketika janin sudah diberi hak hidup oleh Tuhan, kemudian diaborsi tidak dengan alasan "demi melindungi hak keberlanjutan hidup ibunya", maka apa yang diperbuatnya berkategori pelanggaran HAM. 
Aborsi merupakan jenis perbuatan yang bermodus perbuatan merampas hak hidup janin, lebih-lebih jika aborsi itu dilegalisasikannya bukan dengan alasan melindungi hak keberlanjutan hidup atau nyawa janin atau ibu yang mengandungnya. Jadi legalisasi aborsi yang dibenarkan menurut HAM hanya terbatas untuk melindungi keberlanjutan hidup janin dan ibu yang mengandungnya. Jika alasan aborsi hanya sebatas untuk memenuhi hak dan kebebasan ibu dari beban psikis dan social serta kebebasan hidupnya sebagai makhluk yang mempunyai HAM, maka perbuatan aborsi dianggap melanggar HAM.

\section{Aborsi bagi Korban Perkosaan Menurut Hukum Islam}

Di dalam teks-teks Alquran dan Hadist tidak didapati secara khusus hukum aborsi, yang ada adalah bahwa Allah melarang manusia membunuh anak-anaknya karena takut miskin, karena sesungguhnya Allah yang akan memberi rezeki kepada anak- anak tersebut, termasuk kepada para orang tua.Perbuatan membunuh anak itu adalah perbuatan dosa besar sebagaimana dalam Q.s. Al-Isra: 31.

Pada ayat lain, Allah melarang membunuh jiwa orang tanpa hak, sebagaimana firman Allah Swt dalam surat Al-Isra ayat 33:

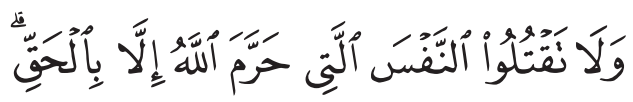

"Dan janganlah kamu membunuh jiwa yang diharamkan Allah (membunuhnya), melainkandengan suatu (alasan) yang benar.” (Q.s. Al Isrầ: 33)

Pada ayat lain Allah berfirman:

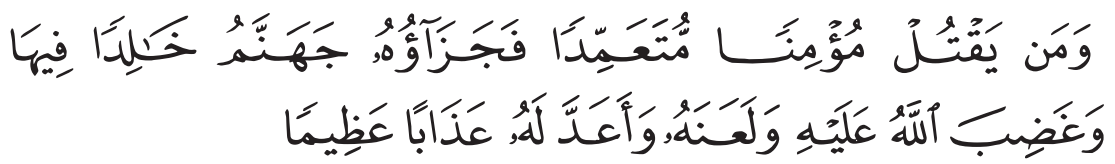

"Dan barang siapa yang membunuh seorang mukmin dengan sengaja, maka balasannya adalah neraka Jahanam, dan dia kekal di dalamnya, dan Allah murka kepadanya dan melaknatnya serta menyediakan baginya adzab yang besar" (Q.s. al-Nisa' : 93) 
Begitu juga hadis yang diriwayatkan oleh Ibnu Mas'ud bahwasanya Rasulullah Saw bersabda:

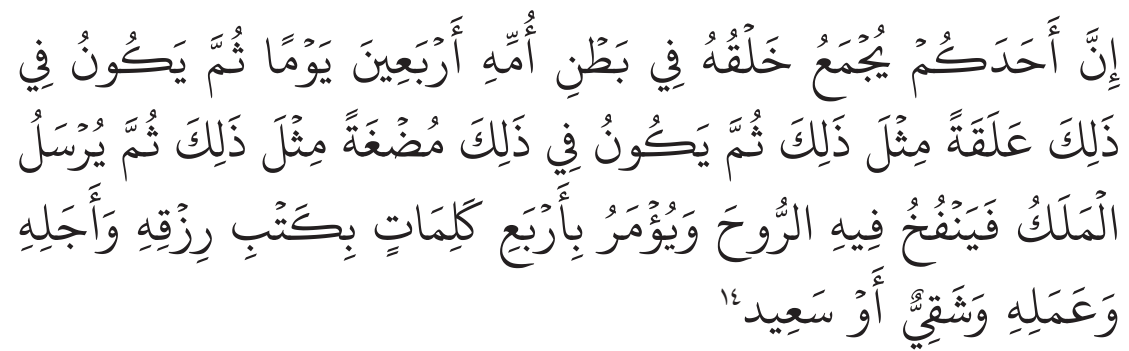

"Sesungguhnya seseorang dari kamu dikumpulkan penciptaannya di dalam perut ibunya selama empat puluh hari. Setelah genap empat puluh hari kedua, terbentuklahsegumlah darah beku. Ketika genap empat puluh hari ketiga, berubahlah menjadi segumpal daging. Kemudian Allah mengutus malaikatuntuk meniupkan roh, serta memerintabkan untuk menulis empat perkara, yaitu penentuan rizki, waktu kematian, amal, serta nasibnya, baik yang celaka, maupun yang bahagia." (Bukhari dan Muslim).

Janin dalam perut ibunya senantiasa dalam pemeliharaan dan naungan Allah. Ia memiliki hak-hak yang seharusnya didapatkannya. Gambaran tentang fase-fase penciptaan manusia dalam Alquran dan hadis membuktikan keagungan Allah dan melemahkan keangkuhan manusia. Allah yang mempunyai hak untuk menentukan kelangsungan hidup janin tersebut, bukan kehendak manusia. Sejalan dengan Firman Allah Swt dalam surat Al-Isra ayat 31.

Ulama klasik membedakan hukum aborsi bagi janin yang sudah mempunyai roh dan yang belum mempunyi ruh:

\section{Menggugurkan Janin Sebelum Peniupan Ruh}

Menggugurkan kandungan yang belum mempunyai roh yaitu yang belum mempunyai umur 120 hari. Dalam hal ini, para ulama klasik berselisih pendapat yaitu:

${ }^{14}$ Muslim An-Nawawi bin Hajaj, Shoheh Muslim, II (Bandung: Dahlan, 451M), h. 451. 
a. Pendapat Pertama

Menggugurkan janin sebelum peniupan roh hukumnya boleh. Pendapat ini dikemukakan oleh Ibnu Abidin dalam mazhab Hanâfi yang mengatakan bahwa "menggugurkan kandungan sebelum janin bernyawa dibolehkan. Janin dipandang bernyawa setelah mengalami perkembangan selama120 hari". ${ }^{15}$

Kebolehan pengguran kandungan sebelum mempunyai roh menurut mazhab ini bila dalam keadaan uzur atau dilakukan karena benarbenar terpaksa demi menyelamatkan ibu.

b. Pendapat kedua

Menggugurkan janin sebelum peniupan roh hukumnya makruh. Ini merupakan pendapat sebagian mazhab Hanâfi yang memandang "makruh menggugurkan kandungan yang belum mempunyai roh, makruh bila dilakukan tanpa uzur". ${ }^{16}$

Mahsjfuk Zuhdi berpendapat bahwa para ulama yang berpendapat makruh menggugurkan kandungan tersebut mempunyai alasan bahwa janin sedang mengalami pertumbuhan ${ }^{17}$, jika sampai pada waktu peniupan ruh, maka hukumnya menjadi haram.

Dalilnya bahwa waktu peniupan ruh tidak diketahui secara pasti, maka tidak boleh menggugurkan janin jika telah mendekati waktu peniupan ruh, demi untuk kehati-hatian. Pendapat ini dianut oleh sebagian ulama mazhab Hanafi dan Imam Romli salah seorang ulama dari mazhab Syâfi'i .

c. Pendapat ketiga

Mazhab Zaidiyah yang merupakan pendapat terkuat dalam mazhab Mâlik berpendapat haram mengeluarkan mani yang telah berada dalam rahim meskipun belum melalui masa 40 hari setelah pembuahan. ${ }^{18}$ Imam Gazâli dari mazhab Syâfi’i juga mengatakan haram, ia mengatakan bahwa terjadinya anak dalam kandungan

\footnotetext{
${ }^{15}$ Ahmad Azhar Basyir, Refleksi Atas Persoalan Keislaman (Bandung: Mizan, 1993), h. 171.

${ }^{16}$ Ahmad Azhar Basyir, Refleksi Atas Persoalan Keislaman h. 171.

${ }^{17}$ Masjfuk Zuhdi, Masail Fiqhiyah (Jakarta: Haji Mas Agung, 1993), h. 81.

${ }^{18}$ Ahmad Azhar Basyir, Refleksi Atas Persoalan Keislaman, h. 170.
} 
melalui tiga tingkatan, tingkat pertama setelah terjadi pembuahan, merusak janin yang demikian merupakan suatu kejahatan, dan bila telah menjadi mudghah dan alaqah, maka merusaknya merupakan kejahatan yang lebih keji, dan jika janin telah ditiupkan roh, maka merusaknya merupakan kejahatan yang lebih keji lagi.

Ketiga pendapat ulama di atas tentunya dalam batas-batas tertentu, yaitu jika di dalamnya ada kemaslahatan, atau karena ada alasan darurat medis atau Abortus Profocatus Therapeuticum, yaitu jika bertujuan untuk kepentingan medis dan terapi serta pengobatan.

\section{Menggugurkan Janin Setelah Peniupan Ruh}

Secara umum, para ulama telah sepakat bahwa menggugurkan janin setelah peniupan roh hukumnya haram. ${ }^{19}$ Peniupan roh terjadi ketika janin sudah berumur empat bulan dalam perut ibu.

Namun jika ada sebab-sebab darurat, seperti jika sang janin nantinya akan membahayakan kesehatan ibunya jika lahir nanti, maka dalam hal ini para ulama berpendapat dibolehkan menggugurkan janin walaupun sudah ditiupkan roh kepadanya, jika hal itu merupakan satu-satunya jalan untuk menyelamatkan ibu dari kematian. Karena menjaga kehidupan ibu lebih diutamakan dari pada menjaga kehidupan janin, karena kehidupan ibu lebih dahulu dan ada secara yakin, sedangkan kehidupan janin belum yakin dan keberadaannya terakhir.

Kebolehan aborsi terhadap janin setelah peniupan roh itu hanya untuk menyelamatkan nyawa ibu, berdasarkan kebolehan kaidah "boleh melanggar bahaya yang paling ringan di antara dua bahaya”. Pada kasus ini, harus dilakukan aborsi karena prediksi tentang keselamatan ibu dan janin bisa dikembalikan ke pada ilmu kedokteran, walaupun hal itu tidak mutlak benarnya.

Terkait aborsi janin akibat perkosaan, sebagian ulama kontemporer berpendapat membolehkan aborsi bagi perempuan yang hamil akibat perkosaan. Di antara mereka adalah Muhammad Sa’id al-Buti dan para

${ }^{19}$ Ahmad Azhar Basyir, Refleksi Atas Persoalan Keislaman, h. 171. 
pendukungnya. Alasannya bahwa wanita tersebut berzina dalam keadaan darurat, yaitu dipaksa untuk melakukan perzinaan. maka kondisi ini dapat membebaskan wanita tersebut dari hukuman had sehingga hal itu dianggap sebagai kondisi darurat. Di sini ia juga berhak untuk melakukan aborsi bila janinnya belum bernyawa. ${ }^{20}$

Senada dengan pendapat tersebut, Sa'duddin al-Hilâli berpendapat boleh aborsi korban perkosaan dengan beberapa ketentuan khusus. Hal ini diungkapkannya dalam makalah risetnya yang berjudul "Aborsi janin hasil korban perkosaan dalam pandangan fikih Islam" yang diterbitkan majalalah Al-Awa'yu al-Islami. Makalah ini ditulisnya sejak maraknya perkosaan wanita di Kuwait dan di Bosnia Herzegovina tahun 1992 yang dilakukan oleh bangsa Serbia. Ia berpendapat bahwa aborsi janin hasil perkosaan dibolehkan, tetapi dengan aturan dan ketentuan khusus. Ketentuan tersebut antara lain:

a. Kasus perkosaan harus terbukti.

b. Aborsi harus dilakukan langsung setelah hilangnya sebab, yaitu perkosaan. Jika wanita tersebut terlambat melakukan aborsi sedangkan dia mampu melakukakannya, maka ia dianggap merelakan dan mengakuinya. Hal itu didukung oleh riwayat Umar r.a. bahwa ia berkata "Perempuan mana saja yang mengakui bapaknya sekerlingan mata, maka ia tidak boleh menafikannya".

c. Janin harus belum berbentuk manusia dan belum bernyawa.

d. Aborsi harus dilakukan dibawah pengawasan medis yang terpercaya untuk menjaga keselamatan ibu.

e. Aborsi harus dilakukan atas permintaan wanita yang diperkosa di hadapan lembaga resmi tertentu untuk memastikan dan membuktikan adanya kasus perkosaan, menjaga kebenaran prosedur dan menangkap pelakunya.

Jika ditinjau dari hukum Islam, bahwa Alquran dan Hadis tidak membahas secara khusus hukum aborsi, surat al-Isra ayat 31 tentang larangan Allah membunuh anak-anaknya karena takut miskin, karena

${ }^{20}$ al-Buti, Mas'alat Tahdid an Nash, t.t., h. 142. 
sesungguhnya Allah yang akan memberi rezeki kepada anak-anak tersebut, termasuk kepada para orang tua. Selanjutnya dalam surat al-Isra ayat 33 Allah juga mengecam orang yang membunuh: Dan janganlah kamu membunuh jiwa yang diharamkan oleh Allah (membunuhnya) melainkan dengan sesuatu (sebab) yang benar.

Aborsi yang disengaja termasuk "membunuh yang diharamkan Allah". Selanjutnya Alquran surat Al-Baqarah ayat 183 menerangkan bagaimana proses penciptaan manusia. Proses yang dijelaskan di sini sama dengan penjelasan ilmiah dari dunia kedokteran. Jadi, perbuatan membunuh anak itu adalah perbuatan dosa besar.

Dengan melihat pendapat ulama klasik yang membedakan hukum aborsi bagi janin yang sudah mempunyai roh dan yang belum mempunyi roh serta pendapat ulama kontemporer yang membolehkanaborsi akibat perkosaan, maka dapat dipahami Islam memandang bahwa alasan perkosaan memang sesuatu alasan yang memang di luar kemampuan manusia. Jadi kebolehan aborsi bagi korban perkosaan harus dilihat kasus per kasus, dengan melihat situasi dan kondisi masing-masing individu.

Hukum aborsi bagi korban perkosaan berbeda-beda melihat situasi dan kondisi masing-masing kasus. Artinya hukum aborsi tidak bisa disamaratakan. Sesuai dengan kaidah fiqih:

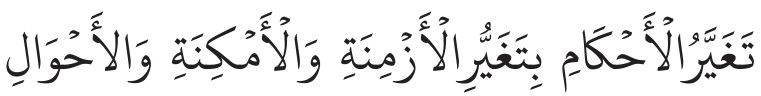

"Hukum-hukum itu bisa berubah sesuai dengan perubahan zaman, tempat dan keadaan"21

Jika korban perkosaan tersebut masih dalam keadaan sehat secara fisik dan gangguan jiwanya masih dalam batas yang wajar dan dapat dikendalikan, ditambah lagi adanya dukungan moril dan materil dari keluarga, sehingga tidak ada kendala yang berarti untuk mempertahankan janinnya. Artinya, jika beban social yang dirasakan oleh korban dapat diatasi dengan dukungan moril dan materil dari keluarga, baik menyangkut nama baik korban maupun tanggung jawab terhadap nafkah dan pendidikan anak yang akan dilahirkan nanti, maka aborsi hukumnya haram. Artinya

${ }^{21}$ Fati Ridwan, Min Falsafah at-Tyasyri' al Islami (Darul Khatib al Arab, 1969), h. 176-177. 
tujuan syariah untuk menjaga akal dan keturunan dapat dipenuhi, maka haram baginya melakukakan aborsi.

Tetapi, jika akibat perkosaan, korban mengalami gangguan psikis yang dikhawatirkan dapat membahayakan korban, dan jika akibat kehamilan itu menyebabkan kecaman dari masyarakat yang menyebabkan dia tidak dapat bersosialisasi di lingkungannya, ditambah lagi tidak ada dukungan moril maupun materil dari keluarga, sehingga dapat memudharatkan korban, maka aborsi boleh atau bahkan sunnah untuk dilakukan. Artinya demi menjaga agama, akal, jiwa dan keturunannya.

Namun, jika korban perkosaan yang mengalami gangguan psikis sangat berat, yang dapat mengganggu kesehatan jiwanya dan secara fisik kehamilan itu membahayakan dirinya, serta tidak adanya dukungan dari keluarga ataupun lingkungannya, bahkan korban dikucilkan dan dipermalukan di tengah masyarakat, dan kondisi seperti ini dapat menyebabkan korban mengalami gangguan jiwa dan berakibat fatal juga kepada fisiknya serta janin yang ada dalam kandungannya, maka aborsi wajib dilakukan. Kewajiban melakukan aborsi tersebut adalah dalam rangka menjaga agama, keselamatan jiwa dan raganya serta akalnya, maka hukumnya wajib.

Kebolehan tersebut dapat dikategorikan kepada keadaan darurat/ uzur, sesuai kaidah fikih bahwa keadaan darurat menghalalkan segala hal yang dilarang. Kebolehan aborsi tersebut sebagaimana ketentuan Undang-Undang yaitu sebelum 40 hari, hal ini sejalan dengan pendapat ulama sebelum janin ditiupkan roh.

Di samping itu kebolehan aborsi juga ditentukan oleh niat atau alasan pelaku melakukan aborsi. Jika dilakukan karena korban mengalami gangguang jiwa/depresi, sehingga memudharatkannya, maka boleh melakukan aborsi, sebagaimana kaidah hukum bahwa hukum itu beredar bersama illatnya, tentang ada dan tidaknya. Maksudnya bahwa ada hukum itu tergantung illatnya. Jika akibat perkosaan menyebabkan seseorang mengalami gangguan jiwa/gila, maka aborsi boleh dilakukan, tetapi jika tidak ada yang mengkhawatirkan baik secara kejiwaan, fisik dan ekonomi, maka aborsi tidak boleh dilakukan.

Adapun kriteria keadaan darurat yang menjadi ukuran tentang 
penetapan hukum melakukan aborsi itu dapat dilihat dari tujuan hukum Islam yaitu untuk penjagaan terhadap 5 (lima) perkara dalam Islam yaitu: Kebutuhan dharûriat (primer) adalah sesuatu yang harus ada demi terwujudnya kehidupan manusia. Kebutuhan dharûriyat disebut juga kebutuhan primer. Bila kebutuhan ini tidak dipenuhi, akan terancam keselamatan umat manusia baik di dunia maupun di akhirat. ${ }^{22}$ Menurut Al-Syâtibi ada lima hal yang termasuk dalam kategori ini yaitu memelihara agama, jiwa, akal, keturunan dan harta.

\section{Penutup}

Tindakan aborsi bagi korban perkosaan menurut PP No 61 Tahun 2014 harus memenuhi kriteria dan prosedur berupa pembuktian usia kehamilan melalui surat keterangan dokter, keterangan penyidik dan keterangan psikolog, konseling pra tindakan dan konseling pasca tindakan. Namun, dalam praktiknya perlu kesadaran dan pengawasan semua pihak, agar tidak terjadi praktik suap dan menyalahgunaan kewenangan bagi pihak yang berkompeten. Jadi aborsi hanya boleh dilakukan jika benar-benar dapat dibuktikan bahwa pemohon aborsi benar-benar korban perkosaan dan mendapat surat keterarangan dari dokter, penyidik dan psikolog.

Menurut HAM, aborsi bagi korban perkosaan hanya boleh dilakukan untuk melindungi jiwa janin dan ibu, selain dari alasan tersebut dianggap sebagai pelanggaran HAM, sedangkan menurut hukum Islam, hukum aborsi berbeda pada setiap kasus tergantung kepada situasi, kondisi dan alasan masing masing-masing pihak yang melakukan aborsi sesuai dengan kaidah hukum Islam bahwa hukum itu berubah sesuai dengan perubahan zaman, tempat dan keadaan, serta kaidah hukum bahwa hukum itu mengikuti illatnya bahwa ada illat ada hukumnya.

Namun dari semua perbedaan hukum tentang aborsi itu, pada prinsipnya semua bertujuan untuk mencapai kemaslahatan manusia sesuai dengan maqâshid syarîah / tujuan hukum Islam dalam menjaga lima perkara yang bersifat darûriyat yaitu memelihara agama, jiwa, akal, keturunan dan harta.

${ }^{22}$ Satria Efendi, Ushul Figh (Jakarta: Kencana, 2005), h. 234. 


\section{Pustaka Acuan}

Askandar, Nur Chozin. “'Hak Untuk Hidup’ dalam Kajian Islam dan Hak Asasi Manusia,” Jurnal An-Natiq, Universitas Islam Malang, (2012), 54.

Andayani, T. R., and I. Setiawan. "Perilaku Seksual Pranikah dan Sikap Terhadap Aborsi." Jurnal Psikologi 2 (2005): 1-9.

Buti, al-. Mas'alat Tahdid an Nash, t.t., 142.

Basyir, Ahmad Azhar. Refleksi Atas Persoalan Keislaman. Bandung: Mizan, 1993.

Dewi. Aborsi: Pro dan Kontra di Kalangan Petugas Kesehatan. Yogyakarta: Pusat Penelitian Kependudukan UGM dan Ford Foundation, 1997. Efendi, Satria. Ushul Fiqh. Jakarta: Kencana, 2005.

Ekotama, dkk. Abortus Provocatus Bagi Korban Perkosaan: Perspektif Viktimologi, Kriminologi dan Hukum Pidana. Yogyakarta: Universitas Atmajaya, 2001.

Ibn Hajaj, Muslim al-Nawawi. Shoheh Muslim. II. Bandung: Dahlan, $451 \mathrm{M}$.

Halim, Paulus Benny. "Abortus Provocatus dalam Perspektif Hak Asasi Manusia." PhD diss., UAJY, 2010.

Hull, Terence H., Sarsanto W. Sarwono, and Ninuk Widyantoro. "Induced Abortion in Indonesia." Studies in Family Planning (1993): 241-251.

Indraswati. "Fenomena Kawin Muda dan Aborsi: Gambaran Kasus," dalam Hasyim S, Menakar 'Harga' Perempuan. Jakarta: Mizan, 1999.

K, Icesmi Sukarni, dan Margareth ZH. Kehamilan, Persalinan dan Nifas. Numed, 2013.

Khisbiyah, Yayah. "Konsekuensi Psikologis dan Sosial-Ekonomi Kehamilan Tak Dikehendaki Pada Remaja.” Populasi 5, no. 2 (1994).

Kuntari, Titik, Siswanto Agus Wilopo, and Ova Emilia. "Determinan Abortus di Indonesia." Kesmas: National Public Health Journal 4, no. 5 (2010): 223-229.

Langie, Yuke Novia. "Tinjauan Yuridis Atas Aborsi di Indonesia (Studi Kasus di Kota Manado).” Lex et Societatis 2, no. 2 (2014). 
Muladi. Hak Asasi Manusia, Hakekat, Konsep dan Implikasinya dalam Perspektif Hukum dan Masyarakat. PT. Rafika Aditama, 2009.

Napitupulu, Annette Anasthasia, and Mahmud Mulyadi. "Pembaharuan Hukum Pidana Terhadap Tindak Pidana Aborsi di Indonesia.” Jurnal Mahupiki 1, no. 1 (2013).

Nursal, Dien GA. "Faktor-faktor yang Berhubungan dengan Perilaku Seksual Murid SMU Negeri di Kota Padang tahun 2007." Jurnal Kesehatan Masyarakat Andalas 2, no. 2 (2008): 175-180.

Pranata, Setia, and F. X. Sadewo. "Kejadian Keguguran, Kehamilan Tidak Direncanakan dan Pengguguran di Indonesia." Buletin Penelitian Sistem Kesehatan 15, no. 2 April (2012).

Rani, Mutiara Puspa. "Analisis Dekriminalisasi Aborsi dalam Peraturan Pemerintah No. 61 Tahun 2014 Tentang Kesehatan Reproduksi." Jurnal Poenale 3, no. 4 (2015).

Ridwan, Fati. Min Falsafah at-Tyasyri' al Islami. Darul Khatib al-Arab, 1969.

Schiffmen, C. Dalto A. dan P. Bello. Mencegah dan Merencanakan Kehamilan. Arcan, 1991.

Susanti, Yuli. "Perlindungan Hukum Bagi Pelaku Tindak Pidana Aborsi (Abortus Provocatus) Korban Perkosaan." Syiar Hukum 14, no. 2 (2012): 79-93.

Syahrizal, Munir. Hak Asasi Manusia: Keadidayaan Kejahatan Kemanusiaan. Jakarta: Presssindo Akademika, 2013.

Soge, Paulinus. "Hukum Aborsi Tinjauan Politik Hukum Pidana Terhadap Perkembangan Hukum Aborsi di Indonesia.” Jurnal Hukum (2010): 1-98.

, "Legalisasi Aborsi di Indonesia Perspektif Perbandingan Hukum Pidana: Antara Common Law System dan Civil Law System.” Jurnal Hukum 16, no. 4 (2009): 441-596.

Singarimbun, Masri. “Beberapa Aspek Aborsi.” Populasi 5, no. 2 (1994).

Sari, Riza Yuniar. "Aborsi Korban Perkosaan Perspektif Hukum Islam dan Hak Asasi Manusia", AL-HUKAMA The Indonesian Journal of Islamic Family Law 03, No. 01, (Juni 2013): 34-81. 
Surjadjaja, Claudia. "Policy Analysis of Abortion in Indonesia: The Dynamic of State Power, Human Need and Women's Right." IDS bulletin 39, no. 3 (2008): 62-71.

Tangko, Novianus. "Tindak Pidana dengan Sengaja Mengobati untuk Menggugurkan Kandungan (Abortus Provocatus) dalam Pasal 299 KUHPidana." Lex Crimen 5, no. 2 (2016).

Zuhdi, Masjfuk. Masail Fiqhiyah. Jakarta: Haji Mas Agung, 1993. 